\title{
The religious administration of Constantine
}

\author{
MORTEN WARMIND \\ University of Copenhagen
}

\begin{abstract}
Much of Håkan Rydving's work deals in one way or another with the influence of Christianity on the Saami-peoples. In my paper I explore how Constantine promoted Christianity through his time as emperor in the laws he issued. It is my argument, that Constantine really did nothing - or very little - that was without precedent, but that his careful method and his longevity as ruler was among the reasons for his success in creating the beginnings of a Christian Empire.
\end{abstract}

Keywords: Roman Empire, Constantine, religious administration, Christianisation, Codex Theodosianus

Håkan Rydving published his thesis 'The End of Drum-Time' in 1993. It is sub-titled 'Religious Change among the Lule Saami, 1670s-1740s', and in it he discusses and clarifies the change of religion which took place in a culture confronted by missionaries working to effect as much change as they could. The work of these missionaries was based on the power of the state, and indeed used physical destruction of the primary religious instruments - drums - as a means of conversion, mirroring the great Christian missionaries like Martin of Tours in the fourth century or possibly the ninth-century missionaries to the north like Ansgar. The story of the conversion of large areas of the globe to Christianity is generally one of force and power - the machinery of a central state and sometimes even a hostile foreign power - being used to promote, propagate, or, if possible, simply force a new religion on a people on the periphery. The 'peaceful' conversion of Iceland is often cited as a counter-example, but it is often forgotten that even in this ideal, and possibly very idealised, tale Olaf Tryggvason's threat to execute Icelanders in Norway loomed quite large over the island.

Of course, Martin, Ansgar, and even Olaf Tryggvason as well as von Westen and other missionaries to the Saami areas saw the matter quite differently. They were doing God's work. They were spending resources in an attempt to save as many souls as possible and battle the evil forces of the world. They were bringing light into the darkness; it would be unreasonable 
to see their work only as manifestations of power. However, it is undeniable that power plays a large part in missionary work.

It is therefore interesting to ponder the conversion of the Roman Empire, which began this centralised process of Christianisation, because this conversion began without any outside impulse, pressure, or obvious reason. I have given a preliminary overview of the process elsewhere (Warmind 2004), where I argue that the choice of Christianity may have been accidental and based on the inclination of the emperor. Many years ago I argued that Christianity was well-suited as the basis for the continuing emperor-cult (Warmind 1993). In the following I will examine in a little more depth what Constantine actually did in relation to the religion of the Roman Empire.

\section{The religious policies of Constantine}

The decision of Constantine to support Christianity is much discussed, and there is certainly no consensus about it. Discussions often focus either on how much of a Christian he was or how much of a shrewd political move he was making. I wish to limit my scope to an examination of his religious policies in general.

In my opinion Constantine's relationship with Christianity has been over-exposed and it is therefore difficult to place in perspective. The sources we have were mostly written by and for Christians, and even our legal texts were collected under the auspices of a Christian emperor in the following century. This makes it difficult to say anything about what Constantine may have done that was uninteresting (or embarrassing) to Christians.

\section{The public religion of Constantine}

There is a continuing academic debate concerning the vexed question of how Christian Constantine was and when he converted. Was his father a Christian? Was his mother? Did he convert after seeing a vision of the labarum? Was it all a sham for political reasons? There may be an answer to some of these questions, but we can never know, of course, if Constantine was really a Christian and nor can we ever agree on exactly what this would have meant or entailed.

This is the chief reason this paper will not deal with motivations, but with whatever legal actions Constantine took in religious policy, as far as they can be ascertained.

The rule of Constantine can be divided into roughly three periods. The first was when he was emperor of the areas controlled by his father from 
306, when the troops proclaimed him Augustus in York, until he defeated Maxentius in the famous battle for Rome at the Milvian Bridge and became master of the western half of the empire. The second lasted from 312 until 325, when he defeated Licinius and became sole emperor. The third, when he ruled as sole emperor or with his sons, lasted until his death at sixty-five in 337. His long reign and the fact that his sons, who continued his policies, succeeded him made him immensely influential, which also made it possible for him to initiate a radical change of religion in the empire. The change was not brought to anything like fruition until the beginning of the fifth century, but Constantine certainly took many important steps.

The various measures he took regarding religious life in the empire are known chiefly from his biographer Eusebius of Caesarea, who quotes some of his letters, speeches, and laws in full, although translated into Greek. Other sources, most notably Lactantius, who was the teacher of Constantine's son Crispus, and an anonymous text called the Origo Constantini, also provide information based on first-hand knowledge.

As Barnes has emphasised $(2011,97)$, Christians as a movement had enjoyed legal protection and the right to own property since the Edict of Gallienus in 259, so when Galerius ended the persecution of Diocletian in April 311 they should have been able to reclaim these rights, and probably did so, in the West, both in the areas ruled by Constantine and by Maxentius. Part of the arrangement made by Constantine and Licinius in Milan in 313 (known as the Edict of Milan) was that these rights should also be extended to Christians in the East, and that confiscated property should be returned. The wording in Latin seems to have been preserved by Lactantius (De mortibus persecutorum 48):

When I, Constantine Augustus and I, Licinius Augustus, had come together at Milan, and conferred together about all things concerning public benefit and security, it seemed to Us that, amongst those things that are profitable to mankind in general, the reverence paid to the Divinity merited Our first and chief attention, so that We would give both the Christians and all others liberty to follow that worship which each of them would like; so that whatever Divinity there is in the Heavenly abode, might be benign and propitious to Us, and to every one under Our government. And therefore We judged it a salutary measure, and one highly consonant to right reason, that no man should be denied leave of attaching himself either to the rites of the Christians, or to whatever other religion his mind directed him, which he sensed was most suitable for himself, so that the supreme Divinity, to 
whose worship We freely devote Ourselves, might continue to vouchsafe His favour and beneficence to Us in all things. (...). ${ }^{1}$

The same text is found in Eusebius's Church History $(10,5,19){ }^{2}$ The small variances that do exist may be the result of his translation of the text into Greek. It would seem the decree's purpose was to confirm the rights of Christians in the empire and to restore religious freedom. The text takes for granted that there is a celestial divinitas, whose favour is necessary. We encounter this divinity again in the arch the Senate presented to Constantine when he visited Rome for his decennalia (tenth anniversary) in 315. The arch

1 Cum feliciter tam ego [quam] Constantinus Augustus quam etiam ego Licinius Augustus apud Mediolanum convenissemus atque universa quae ad commoda et securitatem publicam pertinerent, in tractatu haberemus, haec inter cetera quae videbamus pluribus hominibus profutura, vel in primis ordinanda esse credidimus, quibus divinitatis reverentia continebatur, ut daremus et Christianis et omnibus liberam potestatem sequendi religionem quam quisque voluisset, quod quicquid <est> divinitatis in sede caelesti, Nobis atque omnibus qui sub potestate nostra sunt constituti, placatum ac propitium possit existere. Itaque hoc consilium salubri ac reticissima ratione ineundum esse credidimus, ut nulli omnino facultatem abnegendam putaremus, qui vel observationi Christianorum vel ei religioni mentem suam dederet quam ipse sibi aptissimam esse sentiret, ut possit Nobis summa divinitas, cuius religioni liberis mentibus obsequimur, in omnibus solitum favorem suum benivolentiamque praestare (...).

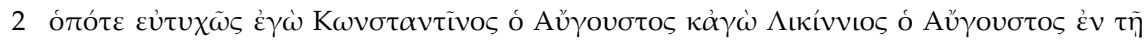

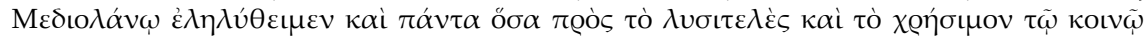

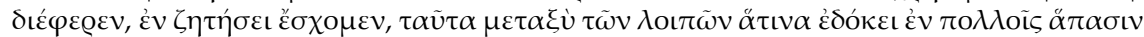

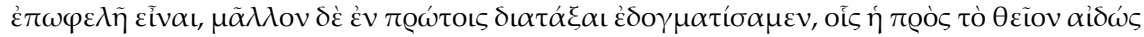

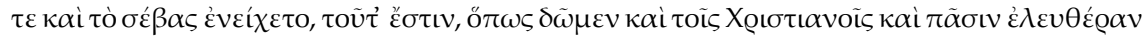

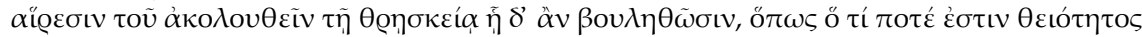

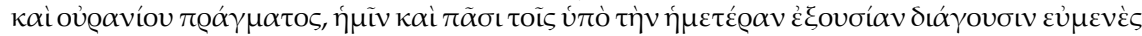

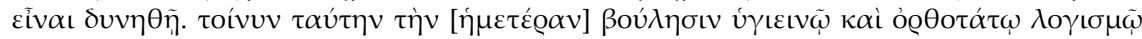

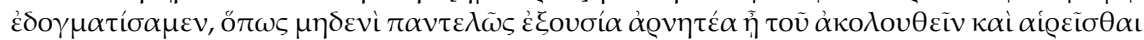

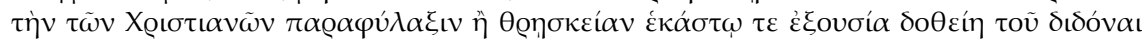

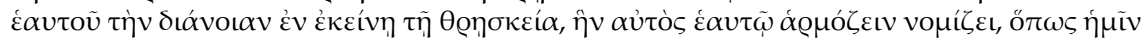

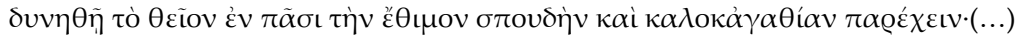

When I, Constantine Augustus, and I, Licinius Augustus, came under favourable auspices to Milan and took under consideration everything which pertained to the common weal and prosperity, we resolved among other things, or rather first of all, to make such decrees as seemed in many respects for the benefit of everyone; namely, such as should preserve reverence and piety toward the deity. We resolved, that is, to grant both to the Christians and to all men freedom to follow the worship which they choose, so that whatever heavenly divinity exists may be propitious to us and to all that live under our government.

We have, therefore, determined, with sound and upright purpose, that liberty is to be denied to no one to choose and to follow the religious observances of the Christians, but that to each one freedom is to be given to devote his mind to that religion which he may think adapted to himself, in order that the Deity may exhibit to us in all things his accustomed care and favour. (...). 
was almost totally constructed from pieces from other buildings in the city, and it is thus in some ways a rather shabby gift. The inscription on both sides proclaims:

The Roman Senate and People dedicated this arch, decorated with triumphs, to the Emperor Caesar Flavius Constantine the Greatest, Pius, Happy, Augustus, because at the prompting of the divinity, by the greatness of his mind, he with his army at one moment by a just victory avenged the Republic as well on the tyrant as on all his faction. ${ }^{3}$

The Senate and the people acknowledged in this monument that the divinity worshipped by Constantine should remain anonymous. Reliefs on the arch show sacrifices to Diana, Hercules, and Apollo - clearly from a Hadrianic monument, but slightly modified to give the impression of the present emperor - or possibly his father. In 315 this was obviously not a problem for Constantine.

\section{A note on the Codex Theodosianus}

Our main source for the laws and decrees of Constantine is the Codex Theodosianus, which grew out of a desire of Theodosius II to obtain an overview of the various decrees and responses ('oracles' as these are poignantly called) of the various Christian emperors. This means that the starting point for the collection was Constantine. Nine men were commissioned to create this edited collection of decrees, both the valid ones and the important ones, which had been recalled or were obsolete. It was an editing process, but the commission in the text we have declares that it has striven to preserve the wording as precisely as possible (CT 1, 1,5). The work was supposed to have led to the weeding out of all contradictions, but thankfully this never happened: this means that many outdated laws were preserved. The main difficulty is that the work was still selective with an obvious Christian bias. Very few laws, for example, of the apostate Julian are preserved, but some that recall them are. Constantine certainly, and possibly also Constantius or even Valentinian, may have issued laws pertaining to practices which

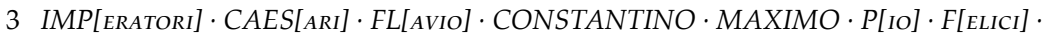

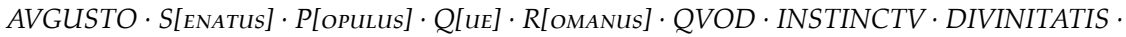
MENTIS $\cdot$ MAGNITVDINE $\cdot C V M \cdot$ EXERCITV $\cdot S V O \cdot T A M \cdot D E \cdot T Y R A N N O \cdot Q V A M \cdot D E$ - OMNI · EIVS · FACTIONE · VNO - TEMPORE - IVSTIS · REMPVBLICAM · VLTVS · EST · ARMIS $\cdot$ ARCVM $\cdot$ TRIVMPHIS $\cdot$ INSIGNEM $\cdot$ DICAVIT 
the committee of Theodosius II found inappropriate. A second difficulty which, though general, is also important, is that we depend of course on a manuscript tradition which is in some places most certainly corrupt. This brief note summarises Curran (2000,161-169). The language in the decrees is difficult and obscure, and for this reason I quote the translations of Clyde Pharr (1952) in the following.

\section{Laws and decrees of Constantine}

He enacted many laws, some were good and equitable, more superfluous, and several severe, and he was the first to attempt to raise the town bearing his name to such dignity, that he could make it a likeness of Rome (Eutropius: Breviarium ab urbe condita, 10,8). ${ }^{4}$

Thus, Eutropius, a non-Christian historian writing in the latter half of the fourth century, sums up the policies of Constantine without mentioning the conversion of the empire or the personal religion of the emperor himself. There are two ways to understand the silence: either the historian was trying to write in the style of the great classical historians, who did not mention religious preferences, or he did not think that Constantine's religious preferences were particularly important. I lean towards the second option, for it is most likely that most inhabitants of the empire regarded Christianity as a matter for the imperial house, and not as something terribly important for them. It was not until about fifty years after the death of Constantine that the situation changed drastically when a new ruling dynasty took the unprecedented step of continuing to support the religion of the House of Constantine and began to make all other religious expressions directly illegal.

If we examine the laws in the Codex Theodosianus the following picture emerges. Of Constantine's laws none is preserved in the Codex predating the Edict of Milan in 313. In October of the same year Constantine made it clear that Christian clergy were to have extensive privileges. They were not to be elected to official and burdensome public posts - specifically, they should not be chosen as tax collectors (CT 16.2.1). A decree dated 319 (CT 16.2.2) and addressed to the governor of Lucania and Bruttium (modern Calabria) is very clear (here and in the following I cite only excerpts of the law's text):

4 Multas leges rogavit, quasdam ex bono et aequo, plerasque superfluas, nonnullas severas, primusque urbem nominis sui ad tantum fastigium evehere molitus est, ut Romae aemulam faceret. 
Those persons who devote the services of religion to divine worship, that is, those who are called clerics (clerici), shall be exempt from all compulsory public services whatever, lest, through the sacrilegious malice of certain persons, they should be called away from divine services. ${ }^{5}$

We may note that even at this time the position of the cleric requires an explanation to make it precise, and the deity remains nameless. Furthermore, Constantine seems to have formed the impression that certain persons were out to bother or irritate the Christian clergy. Such privilege the church could now enjoy must have been very attractive to certain people. In 320 Constantine refers to an older non-extant decree, which apparently had stated that

no decurion or descendant of a decurion or even any person provided with adequate resources and suitable to undertake compulsory public services shall take refuge in the name and the service of the clergy, but that in the place of deceased clerics thereafter only those persons shall be chosen as substitutes who have slender fortunes and who are not held bound to such compulsory municipal services (CT 16.2.3). ${ }^{6}$

In this context decurion is not a military title but the word used for a hereditary class of prominent men in the provincial administrations, who, because of their fortunes, served the community in several different capacities, least popularly as the tax collectors mentioned already. Since the decurion-class comprised the wealthiest men below the class of nobles, Constantine had created a vexing problem for many local communities if decurions became clergy in great numbers: hence the prohibition against their joining the clergy, and the admonition to the church about appointing only poorer people as clergy. The opportunity to use this privilege and to boost the institution's public face as well as infuse capital must have been too great for the church to resist, for we find that the instruction is repeated. Another law from 326 (CT 16.2.6), that is after Nicaea, gives a glimpse of what was

5 Imp. Constantinus a. Octaviano correctori Lucaniae et Brittiorum. Qui divino cultui ministeria religionis impendunt, id est hi, qui clerici appellantur, ab omnibus omnino muneribus excusentur, ne sacrilego livore quorundam a divinis obsequiis avocentur. Dat. XII. kal. nov. Constantino a. v. et Licinio c. coss.

6 (...)nullum (...) decurionem vel ex decurione progenitum vel etiam instructum idoneis facultatibus adque obeundis publicis muneribus opportunum ad clericorum nomen obsequiumque confugere, sed eos de cetero in defunctorum dumtaxat clericorum loca subrogari, qui fortuna tenues neque muneribus civilibus teneantur obstricti, (...). 
happening among the Christian clergy now that Constantine had become sole ruler:

Exemption from compulsory public services shall not be granted by popular consent, nor shall it be granted indiscriminately to all who petition under the pretext of being clerics, nor shall great numbers be added to the clergy rashly and beyond measure, but rather, when a cleric dies, another shall be selected to replace the deceased, one who has no kinship with a decurion family and who has not the wealth of resources whereby he may very easily support the compulsory public services. Thus, if there should be a dispute about the name of any person between a municipality and the clergy, if equity claims him for public service and if he is adjudged suitable for membership in the municipal council through either lineage or wealth, he shall be removed from the clergy and shall be delivered to the municipality. For the wealthy must assume secular obligations, and the poor must be supported by the wealth of the churches. ${ }^{7}$

It seems that decuriones in significant numbers sought to be members of the clergy, and hence exempt from their municipal obligations, and it is implied that the church was making this possible. With this law Constantine was correcting the wholesale set of privileges he had given the church, and he was (re-)empowering the municipality in its relationship with the church. The emperor was even adopting a high moral stance: each party had their obligations to the community.

It can be clearly seen that a religious movement supported and privileged by the emperor could suddenly attract the participation of men from the higher echelons of society. The suddenness can be surmised by the reaction of the emperor himself, who seems not to have expected this result of his benevolence. We may infer from this that decuriones were probably only rarely attracted to Christianity before it was imperially supported, and certainly not as clergy. This is an evidence-based corrective of Stark (1996, 29-47), who

7 (...) Neque vulgari consensu neque quibuslibet petentibus sub specie clericorum a muneribus publicis vacatio deferatur, nec temere et citra modum populi clericis conectantur, sed cum defunctus fuerit clericus, ad vicem defuncti alius allegetur, cui nulla ex municipibus prosapia fuerit neque ea est opulentia facultatum, quae publicas functiones facillime queat tolerare, ita $u$, si inter civitatem et clericos super alicuius nomine dubitetur, si eum aequitas ad publica trahat obsequia et progenie municeps vel patrimonio idoneus dinoscetur, exemptus clericis civitati tradatur. Opulentos enim saeculi subire necessitates oportet, pauperes ecclesiarum divitiis sustentari. Proposita kal. iun. Constantino a. VII et Constantio caes. conss. (326 iun. 1). 
argues that Christianity, as a cult-movement, was a movement of persons of more privileged backgrounds (47). I do not argue that Christians were a proletarian or social movement, but it seems the class of wealthy people came late to it. It can be assumed that similar situations had arisen at previous times in the empire whenever an emperor lent his financial support to one or other religious organisation and privileged its priesthood. This can be inferred from the elite's criticisms concerning unworthy people being raised to high power under Heliogabalus (reigned 218-222) for example, whose monotheistic emperor-centred project in some respects resembled that of Constantine (Warmind 1993, 215f.). However, whereas Heliogabalus was too immature, too unambitious, and much too extreme to succeed and we therefore have no reliable records of what happened with members of his priesthoods during his reign, in the case of the Christians the sources have been preserved. It must be remembered that although the decuriones were wealthy, they were not noble, and indeed they were generally looked down on by the nobility, who are also our main source of information about Heliogabalus. As Salzmann (2002) has shown, members of the noble class, with a few exceptions, did not become Christian until the 370s.

Constantine also took quite drastic steps to greatly enhance the bishops' authority. In his plan to build up the bishops as general authority figures, in 316 Constantine allowed slaves to be manumitted (freed) in a church no less legally than in a normal courtroom if it took place before a bishop (CJ 1.13.1.).

In 318 he even issued a declaration that the episcopal courts were to take precedence over the normal ones, and that anyone could freely transfer his case 'to the jurisdiction of the Christian law' (CT 1.27.1). This would have set Christians apart from the rest of the population, furthering their status as special citizens, and it was certainly an advance for the status of bishops, who were now on a par with judges.

In 321 Constantine declared that Sundays should be considered holidays and that no legal business or preferably any work should be undertaken on these days (only preserved in the Codex Justinianus 3. 12. 7). This is one of the few extant laws of Constantine interfering with business as usual in the empire as such. It was, however, not necessarily an innovation for an emperor to declare a new set of holidays, so the populace probably understood the act in this light. Later that year he again strengthened the bishops' general authority by declaring that any slave freed under the auspices of a bishop would immediately become a Roman citizen (CT 4.7.1). Interestingly, these two initiatives of 321 seem to have been at cross-purposes, as it was necessary to issue a decree (CT 2.8.1) making it legal to free slaves 
on Sundays, even though legal acts were otherwise forbidden. The direct route to citizenship as an incentive to use the church as an instrument for manumission seems, in my opinion, to indicate that people perhaps preferred the well-known courts for such traditional business, for they would not otherwise have needed such additional benefits.

\section{The Jews}

Other religious laws of Constantine deal with the status of the Jews. In a law of 315 the Jews were forbidden to stone Jewish converts to Christianity, something Constantine had apparently heard was happening. In a law dated 330, but which should probably be dated 317, it was affirmed that Jewish clergy had privileges much like those of Christians: they were exempt from the responsibilities of the decuriones (CT 16.8.2). In 321 Constantine had changed his mind on this point and decreed that Jews could be nominated for seats on municipal councils (CT 16.8.3), but the text of the law added: '....in order that something of the former rule may be left them as a solace, We extend to two or three persons from each group the perpetual privilege of not being disturbed by any nominations' ${ }^{8}$. The last law of Constantine pertaining to Jews (CT 16.8.5 of 336) simply reiterates that Jews were not allowed to do anything harmful to a Jew who converted to Christianity.

It is interesting that Constantine treated the Jews very much like secondrate Christians; the only exception concerns Jewish reactions to Jews tempted to convert to Christianity, as many others must have been at this time. Successive generations of emperors would reduce the freedom of Jews as the fourth century ran its course.

\section{The pagans}

A series of Constantine's laws dealt with pagan practices. In 317 a law (CT 9.16.3) was given to the effect that magic performed to harm others should be punished most severely: 'But remedies sought for human bodies shall not be involved in criminal accusation, nor the assistance that is innocently employed in rural districts in order that rains may not be feared for the ripe

8 (...) Verum ut aliquid ipsis ad solacium pristinae observationis relinquatur, binos vel ternos privilegio perpeti patimur nullis nominationibus occupari (...). 
grape harvests...'.9 This is a strongly pragmatic attitude towards popular custom, which makes one wonder what laws of a similarly tolerant nature may be missing. Two laws (CT 9.16.1 and CT 9.16.2) from 319 concern haruspices and are much less accommodating: they might well belong to the 'severe' laws mentioned by Eutropius. The oldest decree prohibited haruspices from ever entering a private home for any reason - even friendship with the owner. Any haruspex who entered a private home must be burned and those associating with them must be exiled to an island. The second law from the same year reiterated the prohibition, but then declared: 'But you who think that this art is advantageous to you, go to the public altars and shrines and celebrate the rites of your custom; for We do not prohibit the ceremonies of a bygone perversion to be conducted openly'.$^{10}$

The word Pharr chooses to translate as 'perversion' is usurpatio, which might more neutrally be translated as 'usage' - a translation I consider much more preferable.

With these harsh decrees against haruspices in mind it is surprising to read the following decree from 320, which was received on 8th March the following year (CT 16.10.1):

Emperor Constantine Augustus to Maximus.

If it should appear that any part of Our palace or any other public work has been struck by lightning, the observance of the ancient custom shall be retained, and inquiry shall be made of the soothsayers as to the portent thereof. Written records thereof shall be very carefully collected and referred to Our Wisdom. Permission shall be granted to all other persons also to appropriate this custom to themselves, provided only that they abstain from domestic sacrifices, which are specifically prohibited..$^{11}$

It appears there were things haruspices could be used for after all, that they had not all been consigned to the flames, and that they could now enter private homes again. The wording of the laws from the previous year begs the question whether they were to be taken seriously at all. They would

9 (...) Nullis vero criminationibus implicanda sunt remedia humanis quaesita corporibus aut in agrestibus locis, ne maturis vindemiis metuerentur imbres (...)

10 Qui vero id vobis existimatis conducere, adite aras publicas adque delubra et consuetudinis vestrae celebrate sollemnia: nec enim prohibemus praeteritae usurpationis officia libera luce tractari.

11 Imp. Constantinus augustus ad Maximum. Si quid de palatio nostro aut ceteris operibus publicis degustatum fulgore esse constiterit, retento more veteris observantiae quid portendat, ab haruspicibus requiratur et diligentissime scriptura collecta ad nostram scientiam referatur, ceteris etiam usurpandae huius consuetudinis licentia tribuenda, dummodo sacrificiis domesticis abstineant, quae specialiter prohibita sunt. 
probably have been almost impossible to enforce and they should possibly be seen as symbolic. It is perhaps also possible that the decrees may have been a legal tool to undertake spurious persecutions of haruspices if an occasion should arise.

To my knowledge this decree, demanding a full official imperial report on portents interpreted by pagan experts and issued in the same year Sundays were declared holidays, has attracted little attention in the scholarship on this period. Its main interest lies in the fact that it is an example of Constantine being explicitly traditional. This lends strong support to the pagan authors at the end of the fourth century - notably Symmachus and Libanius (Or. 30.6) - who invoked Constantine and even Constantius as emperors who gave due respect to the ancient traditions and changed very little when faced with the momentous changes of Gratian and Theodosius.

It is clear Constantius, in making his famous visit to Rome, appointed nobles to the traditional priesthoods: Symmachus mentions this in his Relatio concerning the statue of Victory in the Senate $(3,7)$. Obviously, Constantine must have done the same routinely, and he probably also issued decrees about it, as must have all emperors at least until Gratian (reigned 367-383). Two extant laws of Constantine are salient reminders that the emperor was also concerned with priesthoods he personally may have regarded as frivolous. It is important to note that he demonstrated this concern late in life, as it is often argued that his stance against the old cults became firmer as he grew older (Curran 1996, 77). Apparently, some decuriones in the province of Africa complained that after occupying the priesthoods of flamen or of sacerdos they were forced to become provosts of public post stations, which was obviously beneath their dignity. Constantine agreed with them and prohibited this practice.

As late as 337 he stressed the prohibition against forcing men of these same offices to take on similar jobs, and for the same reason (CT 12.1.21 and 12.5.2). ${ }^{12}$

It therefore appears from much circumstantial evidence that things went on almost as usual in the Roman Empire under Constantine. It is therefore

12 CT 12.1.21: Idem a. ad Felicem praefectum praetorio. Quoniam afri curiales conquesti sunt quosdam in suo corpore post flamonii honorem et sacerdotii vel magistratus decursa insignia praepositos compelli fieri mansionum, quod in singulis curiis sequentis meriti et gradus homines implere consuerunt, iubemus nullum praedictis honoribus splendentem ad memoratum cogi obsequium, ne nostro fieri iudicio iniuria videatur.

CT 12.5.2: (...) Sacerdotales et flamines perpetuos atque etiam duumvirales ab annonarum praeposituris inferioribusque muneribus inmunes esse praecipimus (...). 
problematic that Eusebius writes in his Church History that Constantine decreed that all sacrifices should end. This would indeed have been a major change, but it seems far from certain that it ever happened. Indeed, it is contradicted by the law allowing the public use of haruspices, and possibly also by the law concerning the priesthoods. The uncertainty concerning the flamines and sacerdotes of Africa arises from the claim of some researchers, notably Cameron $(2011,132)$, that these priesthoods at this time were not tied to sacrifices or indeed anything especially religious, but were merely titles of distinction - a claim it is impossible to disprove. There is another somewhat later source which claims that Constantine issued a law prohibiting sacrifices. This source is none other than a decree by Constantine's own son, Constantius, who in 341 declared in a tone of desperation:

Superstition shall cease; the madness of sacrifices shall be abolished. For if any man in violation of the law of the sainted Emperor, Our father, and in violation of this command of Our Clemency, should dare to perform sacrifices, he shall suffer the infliction of a suitable punishment and the effect of an immediate sentence. ${ }^{13}$

It is possible, as Barnes (2014, 109ff.) argues very strongly, that Constantine did at some point decree that blood-sacrifices should cease. In his Life of Constantine $(2,45)$ Eusebius says so expressly. He refers to two laws, vaguely dated as 'about that time', one of which he quotes in full, though not the one which supposedly prohibited oracles and sacrifice. It is strange that such a hugely important decree should have been so completely lost and gone unmentioned by any other contemporary source (I follow Edwards (2015, 308 ) in his rejection of the poet Palladas as a witness). More importantly, the decree of Constantius shows clearly that this law of Constantine, if it was more than a claim which Constantius based on reading Eusebius, had had absolutely no effect. Why else reiterate it so forcefully? And it is a remarkable contradiction that Constantine himself refers to public altars and shrines in the decree on the legal use of haruspices, who needed to kill animals if they still consulted livers.

I would therefore rather follow Curran (1996 and 2000, 169-181), who distinguishes carefully between the personal religious preferences and behaviour of Constantine and his treatment of public religion. Curran reminds us that the laws against haruspices find precedents in previous emperors,

13 Cesset superstitio, sacrificiorum aboleatur insania. Nam quicumque contra legem divi principis parentis nostri et hanc nostrae mansuetudinis iussionem ausus fuerit sacrificia celebrare, competens in eum vindicta et praesens sententia exeratur. 
who also prohibited private investigations of the future, and he mentions that simply the fact that the emperor himself did not sacrifice - as Eusebius declares - does not mean there were no sacrifices. Curran concludes that Constantine '... did not proscribe paganism by banning all sacrifice, nor did he order the closure of the temples' $(2000,181)$. There is little doubt that Constantine had treasures removed from many temples and that he used these treasures to decorate Constantinople, as Eusebius tells us (see Curran 1996, 75 for a discussion). However, even if this was seen by Christians at the time as a despoiling and possibly a closure of temples, it was really nothing new, at least from a local perspective. Constantine's scope may have been wider than usual, but the practice of Roman emperors moving treasure and sculptures from local temples to Rome or any Roman public building was ancient. People may not have seen it as a religious assault.

\section{Conclusion}

Religious or cultural change in general is difficult to deal with. It is probably continuous and most often imperceptible. Only when major changes are the effect of some sort of force, whether internal or external, do they become apparent and require explanation. In trying to analyse such changes one must look at the push and pull factors. Why change, and why in this direction? When such a change is set in motion the perspective becomes one of stick and carrot. It seems obvious that Constantine was mostly using the carrot. Except for his introduction of Sundays as a new set of holidays and his not unprecedented injunctions against private haruspicy, there appears to be no extant contemporary documentation that he used much force to achieve the formidable religious change which was the result of his actions. The carrot is much more obvious: monetary rewards for the clergy and the elevated judicial status for bishops can be shown to have made people of means flock to the emperor's religion in numbers greater than he himself had foreseen. I would claim that Constantine was doing nothing new with these policies, because previous emperors had given extraordinary privileges to priesthoods of the various cults they supported. Perhaps this is part of the reason for his success, coupled with his longevity and the fact that his sons succeeded him.

MORTEN WARMIND is Associate Professor of Sociology of Religion at the Department for Cross-Cultural and Regional Studies at the University of Copenhagen. E-mail: warmind@hum.ku.dk 


\section{Ancient sources}

Eusebius Eusebius' Ecclesiastical history: according to the text of Burton 1872 With an introduction by William Bright, Oxford: Clarendon Press.

Eusebius Über das Leben des Kaisers Konstantin

2011 Friedhelm Winkelmann (ed.) Berlin/Boston: Walter De Gruyter.

Eutropius Eutropii Breviarium ab urbe condita

1992 Carlo Santini (ed.) Berlin/Boston: Walter De Gruyter.

Lactantius De mortibus persecutorum

1984 J. L. Creed (ed. and transl.) Oxford: Clarendon.

Libanius Selected works

1977-1987 Vol 1-2. With an English transl., introduction and notes by A. F. Norman. (Loeb Classical Library 451-2). Cambridge, Mass: Harvard University Press, London: Heinemann.

Origo Constantini Imperatoris/Exerpta Valesiana, pars 1

1939 Translated by J. C. Rolfe. (Loeb Classical Library 331). Cambridge, Mass.: Harvard University Press.

Symmachus Relationes

1872 Gulielmus [Wilhelm] Meyer (ed.) Leipzig: B.G. Teubner.

The Theodosian Code and Novels and the Sirmondian Constitutions.

1952 A Translation, with commentary, glossary, and bibliography by Clyde Pharr in collaboration with T. Sherrer Davidson \& M. Brown Pharr, with an introduction by C. Dickerman Williams. (The corpus of Roman law (Corpus juris romani) vol. 1). Princeton: Princeton University Press.

\section{Literature}

Barnes, T., \& Boxhall, R.

2014 Constantine, Dynasty, Religion and Power in the Later Roman Empire. Chichester: Wiley-Blackwell.

\section{Cameron, A.}

2011 The Last Pagans of Rome. Oxford: Oxford University Press.

\section{Curran, J.}

1996 Constantine and the Ancient Cults of Rome: The Legal Evidence * Greece and Rome, 43(1), 68-80.

2000 Pagan City and Christian Capital: Rome in the Fourth Century. Oxford: Clarendon. 


\section{Edwards, $M$.}

2015 Religions of the Constantinian Empire. Oxford: Oxford University Press.

\section{Rydving, $\mathbf{H}$.}

1993 The End of Drum-Time. Religious Change among the Lule Saami, 1670s1740s (Historia religionum 12). Uppsala: Uppsala University.

\section{Salzman, M. \& ProQuest}

2002 The Making of a Christian Aristocracy: Social and Religious Change in the Western Roman Empire. Cambridge: Harvard University Press.

Stark, R.

1996 The Rise of Christianity: A Sociologist Reconsiders History. Princeton: Princeton University Press.

Warmind, $M$.

1993 The Cult of the Roman Emperor before and after Christianity. Scripta Instituti Donneriani Aboensis, 15, 211-20.

2004 Kristendomens väg från sekt til statsreligion. - O. Hammer \& C. Raudvere (eds), Med gudomlig auktoritet, om religionens kraft i politiken. Göteborg: Makadam. 